\title{
Gegar Wacana dalam Komunikasi Lintas Bahasa Daerah
}

\begin{abstract}
Atikah Solihah*)
Kemajuan dalam bidang teknologi komunikasi dan transportasi memberikan peluang dan ruang yang lebih besar bagi masyarakat pengguna bahasa daerah yang berbeda di Indonesia untuk saling berinteraksi. Sekalipun keberadaan bahasa Indonesia diakui secara sadar sebagai bahasa persatuan, dalam komunikasi antara pengguna bahasa daerah yang berbeda masih sering muncul ungkapanungkapan khas daerah masing-masing. Kemunculannya sering dilakukan secara alami dan spontan sebagai perwujudan dari skemata pengetahuannya yang masih banyak dipengaruhi oleh referensi bahasa daerah. Hal itu sering menimbulkan peristiwa yang aneh dan lucu bagi pendengar yang memahami konteks sebenarnya. Akan tetapi, bagi pelaku yang sedang berkomunikasi, hal itu tidak jarang menimbulkan gegar wacana, yaitu kegagalan membentuk wacana karena pemahaman konteks wacana dan referensi ungkapan yang berbeda dari mitra tutur. Akibatnya, reaksi yang muncul pun berbeda dari yang diharapkan mitra tuturnya. Reaksi itu sering menimbulkan kebingungan atau kemarahan bagi mitra tuturnya.

Gegar wacana merupakan peristiwa bahasa yang sangat berkaitan dengan sosial budaya di masyarakat multietnis. Banyak faktor yang memengaruhi munculnya gegar wacana, di antaranya penguasaan yang kurang seimbang antara bahasa Indonesia dan bahasa daerah. Gegar wacana dapat berawal dari peristiwa bahasa alih kode, campur kode, atau inferensi yang dilakukan seseorang tanpa kesepakatan dan kesadaran dari mitra tuturnya.

Kemunculan peristiwa bahasa berupa gegar wacana dalam masyarakat multietnis dan multibahasa yang memiliki bahasa daerah sebanyak 742 buah seperti di Indonesia (SIL, 2006) peluangnya sangat besar. Bagaimana latar belakang, proses, keunikan, dan pengaruh gegar wacana dalam kehidupan masyarakat dan dalam dunia pendidikan sangat menarik untuk dibahas lebih lanjut.
\end{abstract}

Kata kunci : Wacana, Gegar Wacana, Komunikasi, Bahasa, Bahasa Daerah

\section{Pengantar}

Kemajuan dalam bidang teknologi komunikasi dan transportasi memberikan peluang dan ruang yang lebih besar bagi masyarakat pengguna bahasa daerah yang berbeda di Indonesia untuk saling

\footnotetext{
*) Magister Pendidikan, Pembantu Pimpinan pada Pusat Bahasa, Depdiknas
} 
berinteraksi. Sekalipun keberadaan bahasa Indonesia diakui secara sadar sebagai bahasa persatuan, dalam komunikasi antara pengguna bahasa daerah yang berbeda masih sering muncul ungkapan-ungkapan khas daerah masing-masing. Kemunculannya sering dilakukan secara alami dan spontan sebagai perwujudan dari skemata pengetahuannya yang masih banyak dipengaruhi oleh referensi bahasa daerah. Hal itu sering menimbulkan peristiwa yang aneh dan lucu bagi pendengar yang memahami konteks sebenarnya. Akan tetapi, bagi pelaku yang sedang berkomunikasi, hal itu tidak jarang menimbulkan gegar wacana, yaitu kegagalan membentuk wacana karena pemahaman konteks wacana dan referensi ungkapan yang berbeda dari mitra tutur. Akibatnya, reaksi yang muncul pun berbeda dari yang diharapkan mitra tuturnya. Reaksi itu sering menimbulkan kebingungan atau kemarahan bagi mitra tuturnya. Gegar wacana yang terjadi dalam lingkup wacana lisan, yaitu dalam komunikasi antarpengguna bahasa daerah yang berbeda.

\section{Pembahasan}

\section{1 Bahasa sebagai Bentuk Kebudayaan}

Bangsa Indonesia memiliki 746 bahasa daerah. Tidak semua bahasa daerah tersebut diketahui keberadaannya oleh penutur bahasa daerah lain. Hanya beberapa bahasa yang luas pemakaiannya dapat diketahui secara jelas keberadaannya oleh masyarakat umum sekalipun secara etnolinguistik sudah terpetakan. Di antara bahasa yang luas pemakainya adalah bahasa Jawa, bahasa Sunda, bahasa Minang, bahasa Bali, bahasa Batak, bahasa Aceh, dan bahasa Madura. Masing-masing bahasa menjadi identitas bagi penuturnya yang berkaitan erat juga dengan budaya yang melatarbelakanginya. 
Brown (1980:5) menyatakan bahwa bahasa digunakan sebagai alat komunikasi. Bahasa juga beroperasi dalam suatu masyarakat atau budaya. Sebagaimana sudah diketahui, bahasa merupakan seperangkat lambang-lambang yang bersifat mana suka atau arbitrer. Pembentukan dan pemaknaan suatu kata dalam suatu bahasa dilakukan dengan konvensi masyarakat pemakainya secara mana suka.

Kata-kata dengan sendirinya tidak bermakna apa-apa kecuali diberi makna oleh manusia. Kata-kata bukanlah objek yang diwakilinya, sebagimana peta bukanlah wilayah yang dipetakannya. Jadi ketika kita berbicara dengan orang lain, kita hanya menyampaikan kata-kata, bukan makna. Pembicaraan akan berjalan lancar bila makna yang kita berikan terhadap kata-kata mirip dengan makna yang diberikan orang lain terhadap kata-kata yang sama. Akan tetapi, kenyataannya tidak selalu demikian. Boleh jadi suatu kata yang sama merujuk pada objek yang berbeda atau kata-kata yang berbeda merujuk pada objek yang sama pada dua daerah yang berbeda.

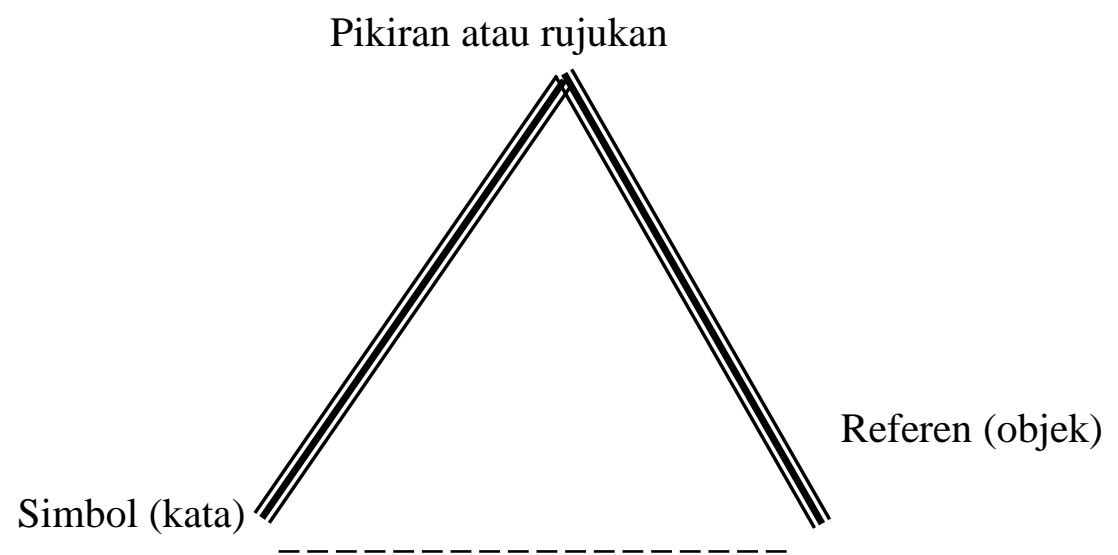

Perbedaan rujukan terhadap suatu kata dan penggunaan kata yang sama untuk rujukan yang berbeda banyak terjadi dalam situasi kebahasaan yang majemuk seperti di Indonesia. Komunikasi yang makin 
4 Mabasan - Vol. 3 No. 2 Juli-Desember 2009: 1--16

meningkat antarpengguna bahasa daerah yang berbeda makin memperjelas adanya berbagai perbedaan rujukan terhadap kata-kata tertentu itu. Kata taksi yang di Jakarta dan di Bandung biasanya bermakna sedan sewaan, di beberapa daerah lain di Indonesia seperti di Kuningan, Tasikmalaya, Palembang, Pontianak, Kendari, dan Papua bermakna angkutan kota (angkot). Daerah lain seperti di Mataram, Lombok, dan Kupang kata bemo digunakan untuk menyatakan angkutan kota beroda empat itu. Di Medan kata motor dipakai untuk merujuk pada mobil, sedangkan sepeda motor disebut kereta. Di Pekanbaru, Padang, dan Flores kata honda digunakan untuk merujuk pada sepeda motor, meskipun merek sepeda motor itu adalah Yamaha atau Vespa. Jika perbedaan tersebut disampaikan tidak dalam konteks berkomunikasi mungkin tidak akan terlalu berpengaruh terhadap hubungan sosial pemakainya. Akan tetapi, jika perbedaan itu ditemukan dalam konteks komunikasi yang nyata, akan tampak pengaruhnya terhadap kehidupan sosial pemakainya.

Seruan "kiri" dari seorang penumpang angkot yang akan turun dari mobil yang ditumpanginya (misalnya di Bandung dan Depok) mungkin tidak lazim di beberapa daerah lain seperti di Manado dan Gorontalo. Di Manado supir tidak akan menghentikan kendaraan umumnya ketika ia mendengar teriakan kiri dari penumpangnya. Kendaraan baru berhenti ketika penumpangnya berteriak muka. Sementara itu, di Padang penumpang berseru siko ciek (di sini satu) kepada supir untuk menandakan ada penumpang yang akan turun meskipun penumpang yang turun lebih dari satu orang atau bahkan seluruh penumpang.

Kata cicing yang bermakna 'diamlah' dalam bahasa Sunda ternyata bermakna 'anjing' dalam bahasa Bali. Seorang mahasiswa asal 
Bali yang menepuk-nepuk punggung seorang mahasiswa Sunda mungkin akan tersinggung ketika mahasiswa Sunda itu berkata cicing. Berikutnya kata ketek dalam bahasa Minang yang artinya 'kecil' mirip dengan kete dalam bahasa Jawa yang artinya monyet. Oleh karena itu, bisa terjadi kalimat ia kan cuma anak ketek yang diucapkan seorang ibu asal Sumatera Barat akan membuat marah seorang ibu asal Jawa Tengah. Kata babiak yang dalam bahasa Minang bermakna 'basah' atau 'lembab' memiliki makna yang berbeda, yaitu 'harimau' dalam bahasa Batak. Dapat dibayangkan seorang pria Batak akan ketakutan ketika mendengar seorang petani Minang berteriak awas babiak.

Larry A. Samovar dan Richard E. Porter mengemukakan enam unsur budaya yang secara langsung memengaruhi ketika kita berkomunikasi dengan orang yang berbeda budaya dengan kita (Mulyana, 2001). Keenam hal itu dapat dijelaskan sebagai berikut.

1) Kepercayaan (beliefs), nilai (values), dan sikap (attiudes)

Kepercayaan adalah anggapan subjektif bahwa suatu objek atau peristiwa memiliki ciri atau nilai tertentu dengan atau tanpa bukti. Kepercayaan itu tidak terbatas, misalnya Tuhan itu Esa, AIDS adalah penyakit berbahaya, dan seorang ibu memiliki rasa kasih sayang yang besar kepada anaknya. Nilai adalah komponen evaluatif dari kepercayaan kita mencakup kegunaan, kebaikan, estetika, dan kepuasan. Nilai biasanya bersumber dari isu filosofis yang lebih besar yang merupakan bagian dari lingkungan budaya karena itu bersifat stabil dan sulit berubah.

2) Pandangan dunia (worldview)

Pandangan dunia adalah orientasi budaya terhadap Tuhan, kehidupan, kematian, alam semesta, kebenaran, materi kekayaan, dan isu-isu filosofis lainnya yang berkaitan dengan kehidupan. Pandangan 
6 Mabasan - Vol. 3 No. 2 Juli-Desember 2009: 1--16

dunia mencakupi agama dan ideologi. Berbagai agama di dunia punya konsep ketuhanan dan kenabian yang berbeda.

3) Organisasi sosial (social organization)

Organisasi-organisasi yang diikuti seseorang, baik formal maupun nonformal juga memengaruhi seseorang dalam memersepsi dunia dan kehidupan yang pada gilirannya memengaruhi perilaku orang itu.

4) Tabiat manusia (human nature)

Pandangan seseorang tentang siapa dirinya dan bagaimana sifat serta wataknya juga memengaruhi cara seseorang dalam memersepsi lingungan fisik dan sosial.

5) Orientasi kegiatan (activity orientation)

Pandangan tentang kegiatan turut memengaruhi persepsi seseorang. Orientasi ini dapat dijabarkan dalam suatu rentang mulai dari siapa dia hingga apa yang dilakukannya. Dalam budaya-budaya tertentu siapa seseorang itu (raja, anak presiden, pejabat, keturunan ningrat) lebih penting daripada apa yang dilakukannya. Oleh karena itu, Sultan Yogyakarta tetap dihormati dan disanjung oleh rakyatnya sekalipun misalnya terdapat gambaran negatif tentang Sultan dari daerah di luar Yogyakarta.

6) Persepsi tentang diri dan orang lain (perception of self and others)

Persepsi tentang diri dan orang lain turut memengaruhi persepsi. Ada lingkungan yang mementingkan individu, ada pula yang sangat mementingkan kolektif. Orang yang individualis kurang terikat dengan kelompoknya, sementara itu orang yang kolektif sangat terikat dengan kelompoknya.

Persepsi yang dibentuk terhadap mitra tutur akan sangat memengaruhi komunikasi yang dijalin. Persepsi dibentuk berdasarkan budaya yang telah dipelajari. Persepsi orang terhadap lingkungannya 
bersifat subjektif. Semakin besar perbedaan budaya dan bahasa antara dua orang, makin besar pula perbedaan persepsi mereka terhadap realitas. Karena tidak ada dua orang yang mempunyai nilai-nilai budaya yang persis sama, tidak pernah ada dua orang yang mempunyai persepsi yang persis sama pula.

Berikut ini ada dua gambar yang terlihat berbeda bila dilihat dengan cara dan persepsi yang berbeda, sekalipun pada hakikatnya bentuk dua gambar tersebut sama.

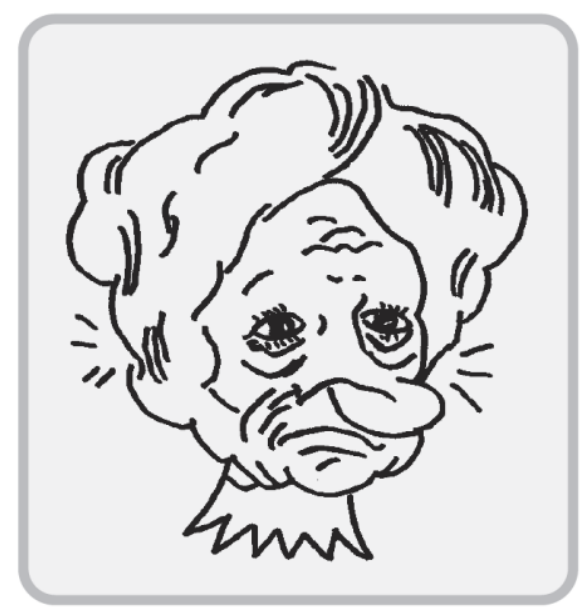

Gambar A1

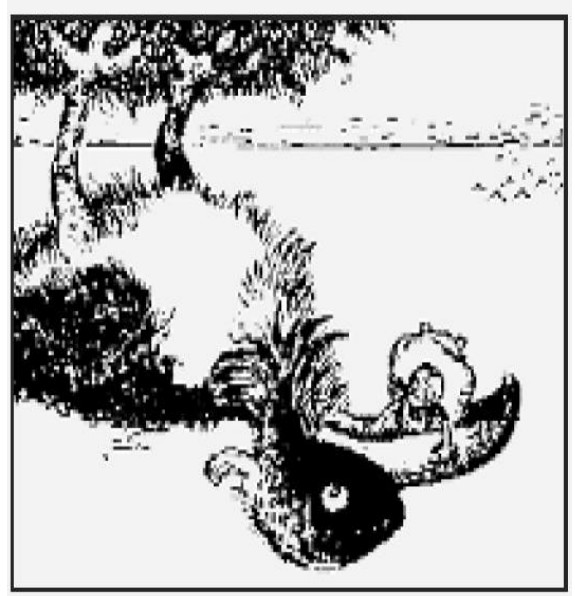

Gambar B1

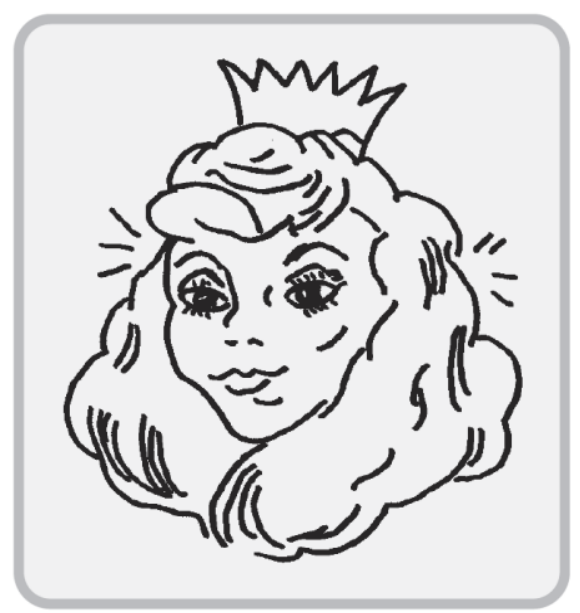

Gambar A2

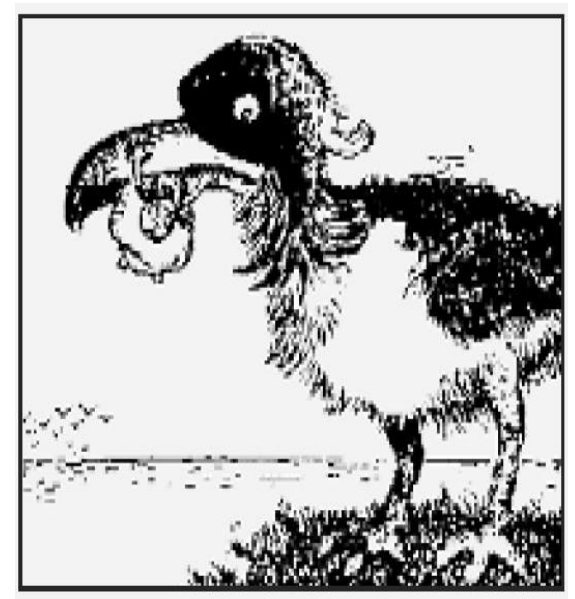

Gambar B2 
Persepsi kita terhadap Gambar A1 adalah lukisan atau gambaran seorang nenek tua berhidung besar yang wajahnya penuh dengan kerutan. Sementara itu, dengan cara pandang yang berbeda, yaitu diputar $180^{\circ}$, gambar tersebut memperlihatkan seorang wanita cantik yang memakai mahkota. Pada Gambar B1 kita dapat melihat suatu pemandangan seorang yang berperahu di danau dekat sebuah pohon besar. Di samping perahu terdapat seekor ikan besar yang sedang melompat. Dengan cara pandang yang berbeda, Gambar B2 memperlihatkan kepada kita tentang seekor anak itik dengan makanan yang tergantung di paruhnya.

\subsection{Wacana Lisan}

Wacana ialah rekaman kebahasaan yang utuh tentang peristiwa komunikasi, biasanya terdiri atas seperangkat kalimat yang mempunyai hubungan pengertian yang satu dengan yang lain. Komunikasi itu dapat menggunakan bahasa lisan, dan dapat pula memakai bahasa tulisan.

Analisis wacana menginterpretasi makna sebuah ujaran dengan memperhatikan konteks, sebab konteks menentukan makna ujaran. Konteks meliputi konteks linguistik dan konteks etnografi. Konteks linguistik berupa rangkaian kata-kata yang mendahului atau yang mengikuti sedangkan konteks etnografi berbentuk serangkaian ciri faktor etnografi yang melingkupinya, misalnya faktor budaya masyarakat pemakai bahasa.

Gegar wacana merupakan peristiwa bahasa yang sangat berkaitan dengan sosial budaya di masyarakat multietnis. Banyak faktor yang memengaruhi munculnya gegar wacana, di antaranya penguasaan yang kurang seimbang antara bahasa Indonesia dan bahasa daerah. Gegar wacana dapat berawal dari peristiwa bahasa alih kode, campur kode, perbedaan referensi, atau inferensi. Inferensi adalah membuat simpulan 
berdasarkan ungkapan dan konteks penggunaannya. Dalam membuat inferensi perlu dipertimbangkan implikatur. Implikatur adalah makna tidak langsung atau makna tersirat yang ditimbulkan oleh apa yang terkatakan (eksplikatur).

Referensi dalam analisis wacana lebih luas dari telaah referensi dalam kajian sintaksis dan semantik. Istilah referensi dalam analisis wacana adalah ungkapan kebahasaan yang dipakai seorang pembicara/penulis untuk mengacu pada suatu hal yang dibicarakan, baik dalam konteks linguistik maupun dalam konteks nonlinguistik. Dalam menafsirkan acuan suatu kata perlu diperhatikan, (a) adanya acuan yang bergeser, (b) ungkapan berbeda tetapi acuannya sama, dan (c) ungkapan yang sama mengacu pada hal yang berbeda.

Dalam analisis wacana berlaku dua prinsip, yakni prinsip interpretasi lokal dan prinsip analogi. Prinsip interpretasi lokal adalah prinsip interpretasi berdasarkan konteks, baik konteks linguistik atau koteks maupun konteks nonlinguistik. Konteks nonlinguistik yang merupakan konteks lokal tidak hanya berupa tempat, tetapi juga dapat berupa waktu, ranah penggunaan wacana, dan partisipan.

Prinsip adalah prinsip interpretasi suatu wacana berdasarkan pengalaman terdahulu yang sama atau yang sesuai. Dengan interpretasi analogi itu, analis sudah dapat memahami wacana dengan konteks yang relevan saja. Hal itu berarti bahwa analis tidak harus memperhitungkan semua konteks wacana.

Wacana lisan memiliki perbedaan dengan wacana tulis. Berikut ini ciri wacana lisan.

1) Wacana lisan cenderung kurang terstruktur (gramatikal) apabila dibandingkan dengan wacana tulis. 
10 Mabasan - Vol. 3 No. 2 Juli-Desember 2009: 1--16

2) Wacana lisan cenderung berisi kalimat yang tidak lengkap, bahkan sering hanya berupa urutan kata yang berupa frasa. Hal itu sangat wajar karena penutur tidak sempat merevisi bahasa yang diucapkannya atau tidak mampu memantau secara terus-menerus bahasa yang digunakannya.

3) Wacana lisan jarang menggunakan peranti penghubung karena didukung oleh konteksnya.

4) Kalimat dalam wacana tulis cenderung berstruktur subjekpredikat, sedangkan kalimat dalam wacana lisan berstruktur tema-rema atau topik-komen.

Contoh:

Tentang hal itu, saya belum tahu.

Tema

Rema

Tidak benar, apa yang kamu katakan itu.

Tema

Rema

5) Dalam wacana lisan sering digunakan sejumlah "pengisi" (filler), misalnya, saya pikir, perlu Anda ketahui bahwa, dan jika Anda mengetahui apa yang saya maksud. Pada wacana tulis jarang digunakan filler tersebut.

6) Wacana lisan sering tidak dalam bentuk struktur yang lengkap karena penutur telah memilki praanggapan tentang petutur. Oleh karena itu, hubungan antara penutur dengan petutur sangat penting untuk menjalin wacana yang utuh.

Gegar wacana sebagai peristiwa bahasa merupakan bentuk wacana lisan yang muncul dalam kehidupan sehari-hari. Kegagalan 
wacana memang tidak selalu terjadi antarpengguna bahasa daerah yang berbeda. Gegar wacana dapat terjadi sekalipun petutur dan penutur dalam satu budaya dan bahasa daerah yang sama. Akan tetapi, peluang dan kecenderungannya akan lebih meningkat pada pengguna bahasa yang berbeda.

Gegar wacana dapat muncul dari stereotip atau pencitraan yakni kegiatan menggeneralisasikan orang-orang berdasarkan sedikit informasi dan membentuk asumsi mengenai mereka berdasarkan keanggotan mereka dalam suatu kelompok. Stereotip merupakan perwujudan terhadap penempatan orang-orang dan objek-objek dalam kategori yang mapan atau dalam penilaian yang dianggap sesuai, bukan berasarkan karakteristik individual mereka. Contoh stereotip misalnya laki-laki berpikir logis, wanita berpikir emosional, orang Meksiko pemalas, orang Cina pandai memasak, orang Batak kasar, dan orang Tasikmalaya tukang kredit.

Stereotip merupakan bagian dari praanggapan yang dibangun tidak berdasarkan pengalaman interaksi, tetapi berdasarkan anggapan umum terhadap suatu kelompok. Praanggapan demikian dapat menyebabkan gegar wacana.

Berikut ini anekdot yang menggambarkan stereotip atau pencitraan terhadap suatu bangsa.

Tiga kelompok orang dari bangsa yang berbeda mengomentari seekor hewan tak dikenal yang lewat di depan mereka.

\footnotetext{
Orang Amerika : "Bagaimana kita bisa mengembangbiakan hewan ini agar jumlahnya bertambah banyak dan kita memperoleh laba dari bisnis peternakan ini?"

Orang Cina : : Bagaimana cara memasak daging hewan ini agar enak dimakan?
} 
12 Mabasan - Vol. 3 No. 2 Juli-Desember 2009: 1--16

Orng Indoensia : "Apakah hewan ini menggigit atau tidak?"

\subsection{Beberapa Kasus Gegar Wacana}

Berikut ini dapat disampaikan beberapa kasus gegar wacana dalam interaksi antarpengguna bahasa daerah yang berbeda.

\section{Kasus pertama}

Seusai salat Jumat seorang pria asal Medan yang baru seminggu berada di Tanah Sunda bingung saat mengetahui sandalnya hilang. Lalu ia bertanya kepada orang-orang di sekitarnya.

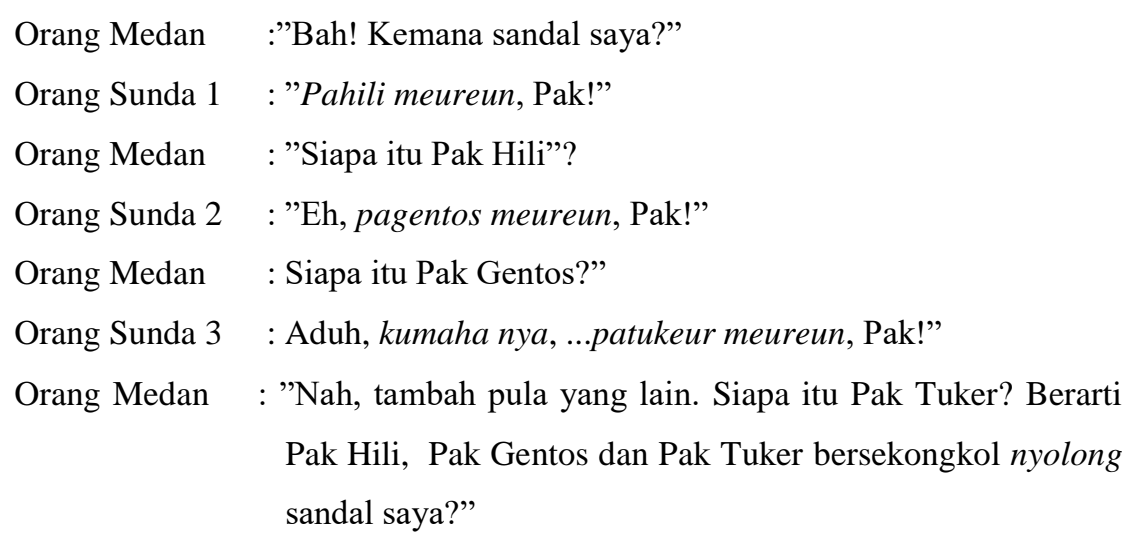

Orang Sunda 1, 2, 3 :"Panginteun."

Kata-kata pahili, pagentos, dan patukeur dalam bahasa Sunda bermakna 'tertukar'. Sementara itu, meureun dan panginten bermakna 'mungkin'. Hanya saja pagentos dan panginten tingkatannya lebih halus. Persepsi awal dalam diri Pria Medan bahwa bunyi [pa] merujuk pada ungkapan bapak/pak, membuat ia segera meganalogikan bunyi [pa] dalam pahili, pagentos, dan patukeur sebagai [pa] dalam Pak Budi atau Pak Lurah. 
Kasus Kedua

Seorang lelaki berkunjung ke Makassar. Suatu hari ia memasuki sebuah restoran. Di dalam restoran itu terjadi dialog berikut ini.

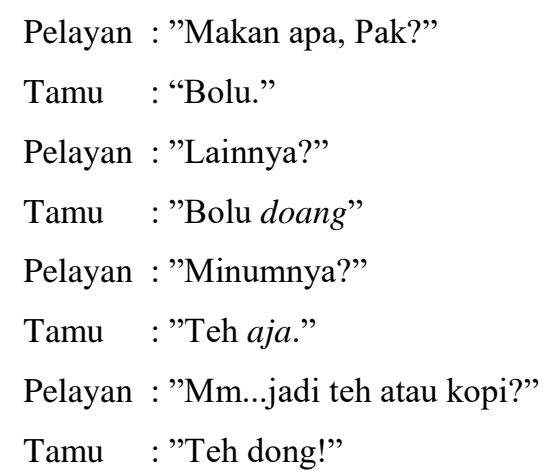

Marahlah sang tamu ketika pelayan menghidangkan masakan yang terdiri atas bandeng, udang, dan daging kerbau. Ia belum mengetahui bahwa dalam bahasa Makassar bolu bermakna 'bandeng', tedong bermakna'kerbau', doang berarti 'udang', dan teaja bermakna 'tidak mau'. Sementara itu, pelayan juga tidak mengetahui bahwa referensi kata-kata tamunya berbeda dengan referensi yang dipahaminya selama ini.

\section{Kasus Ketiga}

Seorang lelaki Padang menikah dengan seorang wanita Jawa. Wanita Jawa itu tidak bisa berbahasa Padang, sebaliknya lelaki Padang itu pun tidak menguasai bahasa Jawa. Untuk menikmati bulan madu, mereka berpergian mengendarai mobil. Sesudah cukup lama berkendaraan, si istri bertanya kepada suaminya, "Mas, capek?". Suami itu langsung menancapkan pedal gas mobilnya sehingga jalannya mobil bertambah kencang. Tak lama kemudian, istrinya bertanya lagi, "Mas, 
capek?" Sang suami mengendarai mobilnya lebih kencang lagi. Melihat suaminya menambah kecepatan mobilnya, sang istri bingung dan cemas. Ia berkata lagi, "Mas, capek?" Si suami akhirnya marah, ”Ini kan sudah capek. Mau tabrakan kamu?!" Istrinya yang bingung akhirnya menyadari telah terjadi kesalahpahaman. Capek dalam bahasa Padang berarti 'cepat'.

\section{Kasus Keempat}

Seorang mahasiswa dari Pulau Jawa diterima di Universitas Tadulako di Sulawesi. Suatu hari, Tyas, mahasiswa itu, dan seorang temannya pergi ke rumah seorang teman barunya. Setelah agak lama berbincang-bincang dengan orang tuanya, si ayah berteriak kepada pembantunya, "Ika! Kasih siram air panas dulu tamu-tamu ini." Kontan saja Tyas panik mendengarnya. Akan tetapi, temannya menenangkan, "Jangan takut. Mereka bermaksud menyuguhi kita minuman."

\section{Kasus Kelima}

Seorang murid SD kelas enam bersuku Sunda menangis sepulangnya dari sekolah pada hari pertamanya di Banjarmasin. Lalu ibunya bertanya "Kenapa kamu menangis?" Putrinya menjawab "Tadi di sekolah saya belajar menghitung dan ibu guru menunjuk saya untuk menjawab pertanyaan. Saya sudah menjawab pertanyaan itu dengan benar, tapi ibu guru malah bilang, "Kamu bujur, kamu bujur, hitungan kamu bujur."

Berdasarkan prinsip bahwa kata semata tidak memiliki makna apapun sebelum diberi konteks dan makna dari penuturnya, makna kata mudah dimanipulasi. Ada adat dalam bahasa Jawa untuk mengungkapkan perbuatan-perbuatan tertentu dengan ungkapan yang dianggap lebih halus 
atau terlihat lebih sopan. Sebagai ilustrasi dapat diceritakan tentang seorang anak kecil yang dibiasakan oleh ibunya untuk mengatakan "nyanyi" bila ia ingin buang air kecil. Hal itu dilakukan untuk menjaga kesopanan ketika sedang bertamu atau sedang menerima tamu.

Suatu saat si anak menginap di rumah neneknya dan ketika ingin buang air kecil, ia berteriak kepada neneknya," Nek, Adi mau nyanyi, Nek."

"Ah, bagus. Mari sini di kuping nenek" jawab nenek dengan gembira sambil tiduran dengan tubuh miring dan memejamkan matanya. Kontan saja sang nenek yang tidak mengetahui kata ajaib itu berteriak kaget ketika sang cucu "menyanyikan' lagunya.

Apa yang disampaikan dalam makalah ini hanya merupakan penggalan proses komunikasi. Tentu saja komunikasi yang sebenarnya tidak berhenti pada titik dalam ilustrasi yang digambarkan. Beberapa pernyataan berikut ini dapat pula berpotensi menjadi gegar wacana dalam komunikasi lintas bahasa daerah.

- Orang Sunda menggunakan kata aliran untuk mati listrik.

- Orang Bogor memanggil remaja lelaki dengan panggilan neng, sedangkan panggilan itu biasanya untuk anak perempuan atau wanita muda di Bandung.

- Orang Menes, Pandeglang, menyebut seorang anak dari bayi hingga remaja dengan sebutan orok dan panggilan rok sebagai kependekannya, seperti dalam kalimat,"Rek, kamana, Rok?"

- Di Pulau Sumbawa, Nusa Tenggara Barat, ada kue tradisional bernama janda berenang.

- Di Limokoto, Bangkinang, Riau, kata besok ternyata bermakna 'dari pagi hingga malam' dan semalam berarti kemarin. 
- Orang Indonesia bagian Timur (Makassar, Ambon, dan Papua) menggunakan kata bunuh untuk listrik, lampu, televisi atau radio, seperti dalam kalimat, "Tolong bunuh lampunya. Sudah siang."

- Suku-suku tertentu di Indonesia senang menyingkat kata dan kalimat dalam percakapan mereka. Di Padang, misalnya, orang lazim bertanya, "Bara?" yang artinya berapa, sedangkan di Papua saya pergi biasa disingkat sapi dan kamu pergi disingkat kopi.

\section{Penutup}

Gegar wacana merupakan peristiwa bahasa yang sering terjadi dalam komunikasi antarpengguna bahasa daerah yang berbeda. Gegar wacana dapat muncul karena perbedaan persepsi, perbedaan referensi, kesalahan inferensi, keterbatasan praanggapan, dan kesalahan analogi berdasarkan skemata atau stereotip tertentu yang dipahami oleh petutur dalam menanggapi ungkapan penutur.

\section{Daftar Pustaka}

Brown, R. (1980). Psycholinguistics. New York: The Free Press.

Hayon, Josep. (2003). Membaca dan Menulis Wacana: Sebuah Petunjuk Praktis bagi Mahasiswa dan Penulis Lainnya. Jakarta: Storia Grafika.

Kushartanti, Untung Yuwono, dan Multamia RMT Lauder. (2000). Pesona Bahasa:Langkah Awal Memahami Lingusitik. Jakarta: Gramedia Pustaka Utama.

Mulyana, Deddy. (2001). Ilmu Komunikasi suatu Pengantar. Bandung: PT Remaja Rosda Karya. 